\title{
Patterns of pain: Meta-analysis of microarray studies of pain
}

\author{
Michael L. LaCroix-Fralish ${ }^{\mathrm{a}, 1}$, Jean-Sebastien Austin ${ }^{\mathrm{a}}$, Felix Y. Zheng ${ }^{\mathrm{b}}$, Daniel J. Levitin ${ }^{\mathrm{a}}$, Jeffrey S. Mogil ${ }^{\mathrm{a}, \mathrm{c}, *}$ \\ ${ }^{a}$ Department of Psychology, McGill University, Montreal, QC, Canada H3A 1B1 \\ ${ }^{\mathrm{b}}$ Department of Anesthesia Research, Faculty of Dentistry, McGill University, Montreal, QC, Canada H3A 1B1 \\ ${ }^{\mathrm{c}}$ Alan Edwards Centre for Research on Pain, McGill University, Montreal, QC, Canada H3A 1 B1
}

Sponsorships or competing interests that may be relevant to content are disclosed at the end of this article.

\section{A R T I C L E I N F O}

\section{Article history:}

Received 20 October 2010

Received in revised form 2 March 2011

Accepted 7 April 2011

\section{Keywords}

Gene expression

Gene chips

Biomarkers

PAP

MCP-1

\begin{abstract}
A B S T R A C T
Existing microarray gene expression profiling studies of tonic/chronic pain were subjected to meta-analysis to identify genes found to be regulated by these pain states in multiple, independent experiments. Twenty studies published from 2002 to 2008 were identified, describing the statistically significant regulation of 2254 genes. Of those, a total of 79 genes were found to be statistically significant "hits" in 4 or more independent microarray experiments, corresponding to a conservative $P<0.01$ overall. Gene ontology-based functional annotation clustering analyses revealed strong evidence for regulation of immunerelated genes in pain states. A multi-gene quantitative real-time polymerase chain reaction experiment was run on dorsal root ganglion (DRG) and spinal cord tissue from rats and mice given nerve (sciatic chronic constriction; $\mathrm{CCI}$ ) or inflammatory (complete Freund's adjuvant) injury. We independently confirmed the regulation of 43 of these genes in the rat-CCI-DRG condition; the genetic correlates in all other conditions were largely and, in some cases, strikingly, independent. However, a handful of genes were identified whose regulation bridged etiology, anatomical locus, and/or species. Most notable among these were Reg $3 b$ (regenerating islet-derived 3 beta; pancreatitis-associated protein) and $\mathrm{Ccl} 2$ (chemokine [C-C motif] ligand 2), which were significantly upregulated in every condition in the rat.
\end{abstract}

(C) 2011 International Association for the Study of Pain. Published by Elsevier B.V. All rights reserved.

\section{Introduction}

The development of high-density oligonucleotide microarray technologies has allowed for the simultaneous assessment of the expression levels of several thousand mRNA transcripts in a single high-throughput procedure [46] (see [29,55] for review). From 2002 to 2008, 20 studies were published describing the use of microarray-based technologies-commonly (albeit not always accurately) referred to as "gene chips"-to profile global gene expression patterns in the central and peripheral nervous system following a variety of neuropathic and inflammatory pain states in rodents. These studies each identified up to hundreds of candidate genes, many of which have yet to be confirmed by followup genetic and/or functional assays. The confirmation and analysis of these genes would greatly increase our understanding of the complex molecular cascades causal to chronic pain, affected by

\footnotetext{
* Corresponding author at: Department of Psychology, McGill University, 1205 Dr. Penfield Ave., Montreal, QC, Canada H3A 1B1. Tel.: +1 514398 6085; fax: +1 514 3984896.

E-mail address: jeffrey.mogil@mcgill.ca (J.S. Mogil).

1 Present address: Regeneron Pharmaceuticals, Inc., 777 Old Saw Mill River Road, Tarrytown, NY 10591, USA
}

chronic pain, and/or useful as correlative biomarkers of chronic pain.

How to interpret the vast amounts of data generated by microarray experiments into meaningful patterns and clusters that can guide the development of novel hypotheses has remained a consistent challenge. In addition, the problems of false-positive findings on a potentially massive scale, and the difficulty in identifying what constitutes a biologically relevant change in gene expression amongst the tens of thousands of mRNA transcripts represented on a modern microarray chip, has led many to question the value these types of studies provide. Simply put, of the hundreds of candidate genes identified by multiple microarray studies as "pain relevant," how should one prioritize single gene-focused follow-up studies? These decisions are usually made with respect to a priori hypotheses, but this strategy obviously limits the potential heuristic value of microarray gene expression profiling as a systematic vehicle for gene discovery. In some cases, regulated genes are chosen for further study based on their ontologies or via bioinformatics analyses (eg, [11,17]). An alternate and completely agnostic approach is to use meta-analytic techniques for the reanalysis of primary data obtained in different published investigations.

Herein, we collected lists of significantly regulated genes from relevant microarray studies in order to identify genes appearing several times in independent experiments. We were thus able to 
find genes that are consistently regulated-that is, over-expressed or under-expressed in pain-relevant tissues taken from animals in chronic pain compared to controls-in different pain states, microarray platforms, species, strains, and laboratories. The results of this analysis identified several genes that are known to have strong links to pain processing, as well as many genes that have never been implicated in pain but now emerged as especially strong candidates for further study. A multi-gene quantitative real-time polymerase chain reaction (qPCR) study was performed to independently confirm these genes; this was broadly successful only for genes expressed in the dorsal root ganglia (DRG) and spinal cord of nerve-injured rats. Altering the pain-causing injury (inflammation) or species (mouse) yielded completely different regulation patterns. However, a few genes were more consistently regulated-especially $\operatorname{Reg} 3 b$ (pancreatitis-associated protein) in rats and mice, and $\mathrm{Ccl} 2$ (chemokine [C-C motif] ligand 2) in rats-these regulations were largely confirmed in a new, singlegene qPCR experiment.

\section{Materials and methods}

\subsection{Literature search and criteria}

A search of the PubMed database (http://www.ncbi.nlm.nih.gov/entrez/) was performed in March 2009 to identify published manuscripts describing microarray experiments utilizing tissues obtained from rodents following the induction of a tonic or chronic neuropathic or inflammatory pain state, and performing geneexpression profiling in these tissues compared to control tissues taken from pain-free rodents. We read each individual manuscript closely in order to ensure relevance. All published manuscripts meeting the following criteria were included for analysis: (1) the manuscript must describe the use of a microarray-based assay containing at least 100 distinct genes analyzed in parallel; (2) the study must have used an established rodent model of either neuropathic or inflammatory pain [34] as the source of tissue for microarray analysis; and (3) the microarray analysis must have been performed on one or more pain-relevant tissues (ie, stimulated peripheral tissue, peripheral nerve carrying afferent information from the stimulated tissue, dermatome-appropriate dorsal root ganglion, dermatome-appropriate dorsal spinal cord). Note that studies involving pain-relevant tissues higher in the neuraxis than the spinal cord would have been considered, but none was identified.

\subsection{Meta-analysis and bioinformatics}

The lists of significantly regulated genes from each identified paper were compiled onto a single Excel spreadsheet. As the original gene lists from individual papers were encoded using several different coding systems (eg, GenBank Accession, Affymetrix ID, gene name), it was necessary to convert these into a single identification code to standardize the information. This was accomplished using the online Gene IDConverter tool (http:// idconverter.bioinfo.cnio.es/) [2]. After standardization, we searched for the number of times that an individual gene was found to be significantly regulated (by the authors' definitions) in the studies examined. Statistical significance was determined by the binomial test. The calculation of binomial probabilities was performed using an online tool (http://faculty.vassar.edu/lowry/ binomialX.html), and used the variables $n$ (number of independent microarray experiments; ie, 20), $k$ (the number of times the gene appears as a "hit" in independent microarray experiments; the definitions of a "hit" in each case are provided in Table 1), and $p$ (the empirical probability of a specific gene being regulated in any one experiment; calculated from the mean of data in the far-right column of Table 1 as $3.87 \%$, or $p=0.0387$ ) in order to calculate the probability $(P)$ of observing any particular regulated gene $k$ or more times in independent microarray experiments.

Each gene significantly regulated in 4 or more studies was coded on an arbitrary 4-point scale as to its level of validation as a "pain gene" based on extensive PubMed searches and a consultation of the PainGenes Database [25] (Table 2). The scale was applied as follows: $0-$ no apparent evidence; 1 -weak correlational evidence (protein or mRNA expressed in pain-relevant cells and/ or anatomical regions); 2-strong correlational evidence (previously demonstrated increase/decrease in protein/mRNA expression in a pain state); and 3-causational evidence (selective pharmacological and/or genetic manipulation alters pain behavior).

Finally, lists of genes were analyzed using the Gene Functional Classification tool from the DAVID Bioinformatics Resources website (http://david.abcc.ncifcrf.gov/) in order to find groups of genes with similar functions based on the controlled Gene Ontology vocabulary [12]. Lists of genes were entered using a classification stringency of "low" due to the relatively small number of total genes in each list. The output was a series of functionally related clusters of genes (called gene groups) ranked by enrichment score, a statistical measure of the overall biological significance of each gene group to the total gene list.

\subsection{Chronic constriction injury}

All behavioral studies were approved by the local animal care and use committee and were conducted in accordance with the guidelines for animal research by the International Association for the Study of Pain [62].

Adult (175-200 g) male Sprague-Dawley rats (Harlan Inc, Indianapolis, IN, USA; Frederick, MD, USA breeding colony) were housed in groups of 3 on sawdust bedding in plastic cages. Adult (25-35 g) male CD-1 (ICR: Crl) mice (Charles River Laboratories, Boucherville, QC) were similarly housed in groups of 4 . These strains (and sex) were chosen based on their common use in the original microarray studies being meta-analyzed here. Artificial lighting was provided on a fixed 12-hour light-dark cycle (lights on at 7:00 am) with food and water available ad libitum. Rodents were anesthetized with sodium pentobarbital $(50 \mathrm{mg} / \mathrm{kg}$, intraperitoneal) and received either a unilateral chronic constriction injury (CCI) or sham procedure (exposure of the sciatic nerve without manipulating it) as described elsewhere [8]. The CCI was chosen over other nerve injuries as the most generalizable, because it has the smallest number of uniquely regulated genes (compared to 2 other surgical procedures leading to neuropathic allodynia: spinal nerve ligation and spared nerve injury) according to the analysis of Griffin and colleagues [17] (also see [11]). Rats (but not mice) receiving the $\mathrm{CCI}$ injury showed the expected changes in the posture of the ipsilateral hind paw (ventroflexed toes and paw inversion) [8]. Although rodents in this particular experiment were not tested behaviorally, all rat and mouse surgeries were performed by highly experienced surgeons in the Bennett and Mogil laboratories, respectively. At 14 days postsurgery, corresponding to the time of peak mechanical allodynia based on our extensive previous experience with these protocols, animals were euthanized for tissue harvesting.

\subsection{Complete Freund's adjuvant}

Rats and mice (see Section 2.3 above) were injected with $50 \%$ complete Freund's adjuvant (CFA) in the plantar surface of the right hind paw ( $20 \mu \mathrm{L}$ volume in mice; $150 \mu$ l volume in rats), or physiological saline as a control. Of the 3 inflammatory mediators used 
Table 1

Methodological summaries of the pain-relevant microarray experiments analyzed.

\begin{tabular}{|c|c|c|c|c|c|c|c|}
\hline References & Year & $\begin{array}{l}\text { Species strain/ } \\
\text { sex }\end{array}$ & Pain assay & Tissue & Microarray platform & Definition of "regulated" & $\begin{array}{l}\text { Number of } \\
\text { regulated } \\
\text { genes } \\
\text { reported } \\
(\% \text { of total })^{\mathrm{a}}\end{array}$ \\
\hline Ko et al. [23] & 2002 & Rat/SD/Male & $\mathrm{S} 1 / \mathrm{S} 2$ transection & Spinal cord & $\begin{array}{l}\text { Incyte Gene Discovery } \\
\text { Array Mouse } 1.1\end{array}$ & $>2$-fold & $42(0.5 \%)$ \\
\hline Costigan et al. [10] & 2002 & Rat/SD/male & $\begin{array}{l}\text { Sciatic nerve } \\
\text { transection }\end{array}$ & DRG & Affymetrix Rat RGU34A & $>1.5$-fold, $\mathrm{P}<0.05$ & $197(2.2 \%)$ \\
\hline Xiao et al. [56] & 2002 & $\begin{array}{l}\text { Rat/SD/not } \\
\text { stated }\end{array}$ & $\begin{array}{l}\text { Sciatic nerve } \\
\text { transection }\end{array}$ & DRG & Atlas Rat $6.5 \mathrm{k}$ & $>2$-fold & $117(1.8 \%)$ \\
\hline Wang et al. [55] & 2002 & Rat/SD/male & SNL & Spinal cord, DRG & Affymetrix Rat RGU34A & $\mathrm{P}<0.05$ & $166(2.4 \%)$ \\
\hline Sun et al. [48] & 2002 & Rat/SD/male & SNL & Spinal cord & Affymetrix Rat RGU34A & $>2$-fold, $\mathrm{P}<0.05$ & $44(0.6 \%)$ \\
\hline Bonilla et al. [9] & 2002 & Mouse/B6/male & $\begin{array}{l}\text { Sciatic nerve } \\
\text { transection }\end{array}$ & DRG & $\begin{array}{l}\text { Incyte Mouse LifeArray } \\
\text { GEM1 }\end{array}$ & $>2$-fold & $13(0.2 \%)$ \\
\hline Kubo et al. [24] & 2002 & Mouse/ICR/male & $\begin{array}{l}\text { Sciatic nerve } \\
\text { transection }\end{array}$ & Sciatic nerve & $\begin{array}{l}\text { Incyte Mouse LifeArray } \\
\text { GEM2 }\end{array}$ & $>2$-fold & $53(0.6 \%)$ \\
\hline Valder et al. [53] & 2003 & $\begin{array}{l}\text { Rat/SD/not } \\
\text { stated }\end{array}$ & SNL & DRG & Affymetrix Rat RGU34A & $>2$-fold, $\mathrm{P}<0.05$ & $139(2.0 \%)$ \\
\hline Yang et al. [58] & 2004 & Rat/SD/male & $\begin{array}{l}\text { Sciatic nerve } \\
\text { transection }\end{array}$ & Spinal cord & Atlas Rat 1.2 & $>2$-fold, $\mathrm{P}<0.05$ & $169(2.6 \%)$ \\
\hline Ren et al. [43] & 2005 & Rat/SD/male & $0.25 \%$ carrageenan $^{\mathrm{b}}$ & Spinal cord & $\begin{array}{l}\text { Custom spotted array } \\
\text { (rat) }\end{array}$ & $\mathrm{P}<0.05, \mathrm{FDR}^{\mathrm{C}}$ & $31(15.1 \%)$ \\
\hline Barr et al. [6] & 2005 & $\begin{array}{l}\operatorname{Rat}^{\mathrm{d}} / \text { not stated } / \\
\text { not stated }\end{array}$ & $2 \%$ formalin & Spinal cord & $\begin{array}{l}\text { Affymetrix Rat } \\
\text { Neurobiology }\end{array}$ & $\mathrm{P}<0.05, \mathrm{FDR}^{\mathrm{c}}$ & $47(3.7 \%)$ \\
\hline Nesic et al. [35] & 2005 & Rat/SD/male & $\mathrm{SCI}$ & Spinal cord & Affymetrix Rat RGU34A & $\begin{array}{l}>1.5 \text {-fold up, }>0.66 \text {-fold } \\
\text { down, } \mathrm{P}<0.05\end{array}$ & $36(0.1 \%)$ \\
\hline $\begin{array}{l}\text { Rodriguez Parkitna } \\
\text { et al. [45] }\end{array}$ & 2006 & Rat/Wistar/male & $150 \mu \mathrm{L}$ CFA, CCI & Spinal cord, DRG & Atlas Rat $4 \mathrm{k}$ & Z-score $>|3.5|$ & $40(1.0 \%)$ \\
\hline $\begin{array}{l}\text { LaCroix-Fralish } \\
\text { et al. [27] }\end{array}$ & 2006 & Rat/SD/male & $\begin{array}{l}\text { SNL, L5 nerve root } \\
\text { ligation }\end{array}$ & Spinal cord & Affymetrix Rat RAE230A & $\mathrm{P}<0.01$ & $805(17.1 \%)$ \\
\hline Yang et al. [57] & 2007 & Rat/SD/male & $4 \%$ carrageenan & DRG, hind paw & SuperArray GEA (rat) & $>2$-fold & $35(16.1 \%)$ \\
\hline Geranton et al. [16] & 2007 & Rat/SD/male & $10 \mu \mathrm{L}$ CFA & Spinal cord & Affymetrix Rat RAE230 & $>1.3$-fold, $\mathrm{P}<0.05$ & $74(0.2 \%)$ \\
\hline Griffin et al. [17] & 2007 & Rat/SD/male & CCI, SNI, SNL & Spinal cord & Affymetrix Rat RGU34A & $>1.25$-fold, $\mathrm{P}<0.01$ & $96(1.1 \%)$ \\
\hline $\begin{array}{l}\text { Yukhananov et al. } \\
\text { [59] }\end{array}$ & 2008 & Rat/SD/male & $2 \%$ carrageenan & Spinal cord & Affymetrix Rat RAE230 & $\mathrm{P}<0.01$ & $798(2.6 \%)$ \\
\hline Nishida et al. [36] & 2008 & Rat/SD/male & $\begin{array}{l}\text { Paclitaxel-induced } \\
\text { neuropathy }\end{array}$ & DRG & Affymetrix Rat RG230 2.0 & $>2$-fold & $51(0.3 \%)$ \\
\hline Levin et al. [28] & 2008 & $\begin{array}{l}\text { Rat/not stated/ } \\
\text { not stated }\end{array}$ & SNL & $\begin{array}{l}\text { Spinal cord, sciatic } \\
\text { nerve, DRG }\end{array}$ & $\begin{array}{l}\text { Affymetrix Rat RGU34A, } \\
\text { B, C }\end{array}$ & $>3$-fold & $195(1.3 \%)$ \\
\hline
\end{tabular}

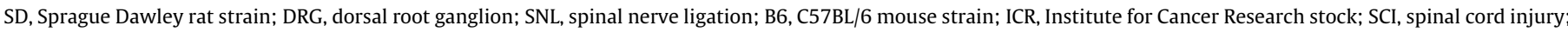
CFA, complete Freund's adjuvant; $\mathrm{CCI}$, chronic constriction injury; SNI, spared nerve injury.

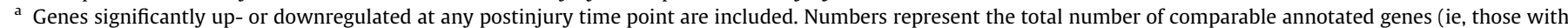

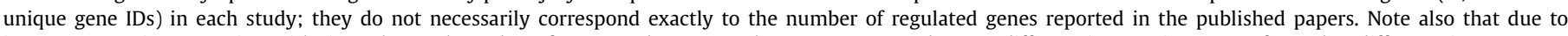
improvements in annotation with time, the total number of annotated genes on the same array can be very different in experiments performed at different times.

b Injections given at 3 days of age and in adulthood, 1 day before tissue extraction.

c False discovery rate (FDR) correction for multiple comparisons [7].

d Rats tested were 3 or 21 days of age.

Table 2

List of genes found to be significantly regulated by 4 or more independent microarray experiments.

\begin{tabular}{|c|c|c|c|c|c|c|}
\hline Entrez gene ID & $\begin{array}{l}\text { No. of } \\
\text { studies } \\
\text { (out of 20) }\end{array}$ & Direction & $\begin{array}{l}\text { Neuropathic/ } \\
\text { inflammatory } \\
\text { (out of } 14 / 6 \text { ) }\end{array}$ & Gene name & Protein name & Validation level $^{\mathrm{a}}$ \\
\hline 50654 & 9 & Up & $8 / 1$ & Ctss & Cathepsin S & 3 \\
\hline 29687 & 8 & Up & $7 / 1$ & $C 1 q b$ & Complement component 1 , q subcomponent, beta & 2 \\
\hline 25211 & 8 & Up & $7 / 1$ & Lyz1 & Lysozyme & 1 \\
\hline 362634 & 7 & Up & $7 / 0$ & $C 1 q c$ & Complement component 1 , q subcomponent, gamma & 2 \\
\hline 24604 & 7 & Up & $7 / 0$ & Npy & Neuropeptide Y & 3 \\
\hline 116510 & 7 & Up & $5 / 2$ & Timp1 & Tissue inhibitor of metalloproteinase 1 & 1 \\
\hline 29461 & 7 & Up & $4 / 3$ & $\operatorname{Vgf}$ & VGF nerve growth factor, inducible & $3^{*}$ \\
\hline 25399 & 6 & Up & $6 / 0$ & Cacna2d1 & Calcium channel, voltage-dependent, alpha2/delta1 & 3 \\
\hline 25599 & 6 & Up & $6 / 0$ & $C d 74$ & Cd74 antigen & 0 \\
\hline 81657 & 6 & Down & $3 / 3$ & Gabbr1 & Gamma-aminobutyric acid (GABA) b receptor 1 & 3 \\
\hline 29141 & 6 & Up & $6 / 0$ & Gal & Galanin & 3 \\
\hline 24387 & 6 & Up & $6 / 0$ & Gfap & Glial fibrillary acidic protein & 2 \\
\hline 24588 & 6 & Down & $5 / 1$ & Nefm & Neurofilament 3 , medium & 2 \\
\hline 294273 & 6 & Up & $5 / 1$ & $R T 1-D M b 1^{\mathrm{b}}$ & Major histocompatibility complex, class II, dm beta & 0 \\
\hline 25012 & 6 & Down & $6 / 0$ & Snap25 & Synaptosomal-associated protein 25 & 1 \\
\hline 24797 & 6 & Up & $6 / 0$ & Sst & Somatostatin & 3 \\
\hline 117556 & 6 & Down & $5 / 1$ & $S v 2 b$ & Synaptic vesicle glycoprotein $2 b$ & 1 \\
\hline
\end{tabular}


Table 2 (continued)

\begin{tabular}{|c|c|c|c|c|c|c|}
\hline Entrez gene ID & $\begin{array}{l}\text { No. of } \\
\text { studies } \\
\text { (out of } 20 \text { ) }\end{array}$ & Direction & $\begin{array}{l}\text { Neuropathic/ } \\
\text { inflammatory } \\
\text { (out of } 14 / 6 \text { ) }\end{array}$ & Gene name & Protein name & Validation level $^{\mathrm{a}}$ \\
\hline 24806 & 6 & Up & $5 / 1$ & Tac1 & Tachykinin 1 & 3 \\
\hline 24877 & 6 & Down & $6 / 0$ & Vsnl1 & Visinin-like 1 & 0 \\
\hline 29427 & 5 & Up & $4 / 1$ & Aif1 & Allograft inflammatory factor 1 (Iba1) & 2 \\
\hline 25239 & 5 & Up & $5 / 0$ & Apod & Apolipoprotein d & 1 \\
\hline 24211 & 5 & Down & $4 / 1$ & Atp1a1 & ATPase, $\mathrm{Na}+/ \mathrm{K}+$ transporting, alpha 1 polypeptide & 1 \\
\hline 24233 & 5 & Up & $4 / 1$ & $C 4 a$ & Complement component $4 \mathrm{a}$ & 2 \\
\hline 24241 & 5 & Up & $4 / 1$ & Calca & Calcitonin/calcitonin-related polypeptide, alpha & 3 \\
\hline 361673 & 5 & Up & $4 / 1$ & Cxcl10 & Interferon-inducible protein variant 10 & 2 \\
\hline 25112 & 5 & Up & $5 / 0$ & Gadd45a & Growth arrest and DNA-damage-inducible 45 alpha & 2 \\
\hline 29423 & 5 & Up & $5 / 0$ & Gap43 & Growth associated protein 43 & 1 \\
\hline 81682 & 5 & Up & $5 / 0$ & Lum & Lumican & 1 \\
\hline 83613 & 5 & Down & $5 / 0$ & Nefl & Neurofilament, light polypeptide & 1 \\
\hline 29480 & 5 & Down & $4 / 1$ & $\operatorname{Rgs} 4$ & Regulator of G-protein signaling 4 & 2 \\
\hline 294274 & 5 & Up & $3 / 2$ & $R T 1-D M a^{\mathrm{c}}$ & Major histocompatibility complex, class II, dm alpha & 0 \\
\hline 29571 & 5 & Down & $5 / 0$ & Scn10a & Sodium channel, voltage-gated, type 10 , alpha & 3 \\
\hline 24230 & 5 & Up & $5 / 0$ & Tspo & Benzodiazepine receptor, peripheral & 3 \\
\hline 25624 & 5 & Down & $5 / 0$ & Vamp1 & Vesicle-associated membrane protein 1 & 1 \\
\hline 117064 & 5 & Up & $5 / 0$ & Vip & Vasoactive intestinal polypeptide & 3 \\
\hline 25291 & 4 & Up & $3 / 1$ & Anxa3 & Annexin A3 & 2 \\
\hline 100363366 & 4 & Up & $3 / 1$ & Aplp2 & Amyloid beta (a4) precursor-like protein 2 & 0 \\
\hline 25728 & 4 & Up & $3 / 1$ & Apoe & Apolipoprotein E & 3 \\
\hline 29221 & 4 & Up & $4 / 0$ & $\operatorname{Arg} 1$ & Arginase 1 & 2 \\
\hline 54227 & 4 & Up & $4 / 0$ & Arpc1b & Actin related protein $2 / 3$ complex, subunit $1 \mathrm{~b}$ & 0 \\
\hline 25389 & 4 & Up & $4 / 0$ & Atf3 & Activating transcription factor 3 & 2 \\
\hline 25390 & 4 & Up & $2 / 2$ & Atp1b3 & ATPase, $\mathrm{Na}+/ \mathrm{K}+$ transporting, beta 3 & $3^{*}$ \\
\hline 192262 & 4 & Up & $4 / 0$ & C1s & Complement component $1, \mathrm{~s}$ subcomponent & 2 \\
\hline 24232 & 4 & Up & $4 / 0$ & C3 & Complement component 3 & 2 \\
\hline 24770 & 4 & Up & $4 / 0$ & $\mathrm{Ccl} 2$ & Monocyte chemoattractant protein-1 & 3 \\
\hline 58919 & 4 & Up & $3 / 1$ & Ccnd1 & Cyclin D1 & 0 \\
\hline 25101 & 4 & Down & $4 / 0$ & Chrna3 & Cholinergic receptor, nicotinic, alpha polypeptide 3 & 3 \\
\hline 64036 & 4 & Down & $3 / 1$ & Cd55 & Decay accelerating factor 1 (CD55, complement) & 0 \\
\hline 29593 & 4 & Down & $4 / 0$ & Ckmt1 & Creatine kinase, mitochondrial 1 , ubiquitous & 1 \\
\hline 155151 & 4 & Up & $4 / 0$ & Coro1a & Coronin, actin binding protein $1 \mathrm{a}$ & 1 \\
\hline 29563 & 4 & Up & $4 / 0$ & Crabp2 & Cellular retinoic acid binding protein 2 & 0 \\
\hline 117505 & 4 & Up & $4 / 0$ & Csrp3 & Cysteine and glycine-rich protein 3 & 1 \\
\hline 171293 & 4 & Up & $3 / 1$ & Ctsd & Cathepsin D & 0 \\
\hline 25425 & 4 & Up & $4 / 0$ & Ctsh & Cathepsin $\mathrm{H}$ & 0 \\
\hline 25417 & 4 & Down & $4 / 0$ & Dpysl4 & Dihydropyrimidinase-like 4 & 0 \\
\hline 24330 & 4 & Up & $2 / 2$ & Egr1 & Early growth response 1 & 3 \\
\hline 289211 & 4 & Up & $4 / 0$ & Fcgr $2 b$ & Fc receptor, IgG, low affinity IIb & 0 \\
\hline 29707 & 4 & Up & $2 / 2$ & Gabra5 & Gamma-aminobutyric acid a receptor, alpha 5 & 1 \\
\hline 25454 & 4 & Up & $4 / 0$ & Gfra1 & Glial cell line derived neurotrophic factor family receptor alpha 1 & 3 \\
\hline 29559 & 4 & Down & $4 / 0$ & Grik1 & Glutamate receptor, ionotropic, kainate 1 & 3 \\
\hline 79246 & 4 & Down & $3 / 1$ & Htr3a & 5-Hydroxytryptamine (serotonin) receptor 3a & 3 \\
\hline 24484 & 4 & Up & $3 / 1$ & Igfbp3 & Insulin-like growth factor binding protein 3 & 1 \\
\hline 25641 & 4 & Up & $3 / 1$ & Igfbp6 & Insulin-like growth factor binding protein 6 & 1 \\
\hline 246153 & 4 & Down & $3 / 1$ & Kcnc2 & Potassium voltage gated channel, shaw-related subfamily, 2 & 1 \\
\hline 498335 & 4 & Up & $4 / 0$ & LOC498335 & Similar to small inducible cytokine b13 precursor ( $\mathrm{Cxcl} 13)$ & 0 \\
\hline 24567 & 4 & Up & $1 / 3$ & Mt1a & Metallothionein $1 \mathrm{a}$ & 0 \\
\hline 24587 & 4 & Down & $4 / 0$ & Nefh & Neurofilament, heavy polypeptide & 2 \\
\hline 60355 & 4 & Down & $4 / 0$ & Nsf & N-ethylmaleimide sensitive fusion protein & 2 \\
\hline 64636 & 4 & Down & $3 / 1$ & Ntsr 2 & Neurotensin receptor 2 & 3 \\
\hline 25531 & 4 & Down & $4 / 0$ & Rab3a & Rab3a, member ras oncogene family & 1 \\
\hline 24618 & 4 & Up & $4 / 0$ & $\operatorname{Reg} 3 b$ & Pancreatitis-associated protein & $2^{*}$ \\
\hline 309622 & 4 & Up & $4 / 0$ & $R T 1-B b^{\mathrm{d}}$ & Rt 1 class II, locus bb & 0 \\
\hline 294269 & 4 & Up & $4 / 0$ & $R T 1-D a^{\mathrm{e}}$ & Rt1 class II, locus da & 0 \\
\hline 294270 & 4 & Up & $4 / 0$ & RT1-Db1 ${ }^{\mathrm{f}}$ & Rt 1 class II, locus db1 & 0 \\
\hline 24615 & 4 & Up & $3 / 1$ & S100a4 & S100 calcium-binding protein a4 & 2 \\
\hline 29701 & 4 & Down & $4 / 0$ & Scn11a & Sodium channel, voltage-gated, type XI, alpha (NaV1.9) & 3 \\
\hline 499660 & 4 & Up & $4 / 0$ & Sprr1al ${ }^{\mathrm{g}}$ & Similar to cornifin a (small proline-rich protein $1 \mathrm{a})$ & 0 \\
\hline 79423 & 4 & Up & $4 / 0$ & Stmn4 & Stathmin-like 4 & 1 \\
\hline 56010 & 4 & Down & $3 / 1$ & Ywhag & 14-3-3gamma & 0 \\
\hline
\end{tabular}

a Evidence for involvement in pain: 0-no evidence; $1-$ weak, correlational evidence; $2-$ strong, correlational evidence; 3-causational evidence (see text for details).

b The equivalent mouse ortholog is H2-Dmb1.

c The equivalent mouse ortholog is H2-Dma.

d The equivalent mouse ortholog is H2-Ab1.

e The equivalent mouse ortholog is H2-Ea-ps.

$\mathrm{f}$ The equivalent mouse ortholog is H2-Eb1.

$g$ The equivalent mouse ortholog is Sprr1a.

* Evidence published in the literature after our validation effort.

in the 6 relevant microarray studies-formalin, carrageenan, and CFA-we chose CFA because in our hands it produces the most robust and long-lasting evidence of pain-related behavior. At $24 \mathrm{~h}$ postinjection, corresponding to the time of peak mechanical 
allodynia based on our previous experience, animals were euthanized for tissue harvesting. Hind paws were weighed immediately post mortem to confirm inflammation. Data from one mouse with insufficient inflammation was discarded from further analysis.

\subsection{Quantitative real-time $R T-P C R(q P C R)$}

Rat and mouse quadrisected (ipsilateral dorsal) lumbar spinal cord and L4-L5 DRG were harvested and total RNA was isolated with TRIzol (Invitrogen, Carlsbad, CA, USA) and the RNeasy kit (Qiagen, Mississauga, ON, Canada) followed by a DNase treatment. To obtain enough total RNA for qPCR, DRG and spinal cord tissue was pooled ( 2 rats/spinal cord, 3 rats/DRG, 3 mice/spinal cord, 4 mice/DRG) from similarly treated animals. RNA quality was assessed on a Bioanalyzer 2100 (Agilent, Santa Clara, CA, USA) and the concentration measured on a NanoDrop spectrophotometer (Thermo Scientific, Wilmington, DE, USA).

For the multi-gene qPCR experiment, custom 384-well qPCR plates were prepared by SA Biosciences (Custom $\mathrm{RT}^{2}$ Profiler PCR Arrays; Frederick, MD, USA) containing species-specific primers corresponding to transcripts of the 79 genes listed in Table 2, as well as 5 housekeeping genes (Actb, Gapdh, B2m, Gusb and Hprt1). Quality control was achieved via the observation of single peaks by RT-PCR, $\mathrm{Ct}<30$, and $>80 \%$ efficiency by DART-PCR (www.sabiosciences.com/pcrarrayperformance.php). Total RNA was reverse transcribed (RT) using the $\mathrm{RT}^{2}$ First Strand Kit, and after quality control for RT efficiency transcripts were amplified on the custom qPCR plates with $\mathrm{RT}^{2}$ Master Mixes containing SYBR Green on an ABI Prism 7900HT Sequence Detection System (Applied Biosystems, Carlsbad, CA, USA). Data were analyzed by the manufacturer's supplied software, using the $2^{-\Delta \mathrm{Ct}}$ method as a ratio compared to the average of the housekeeping genes. In the multi-gene study, each reported fold-regulation ratio (CCI vs sham, CFA vs saline) comprises pooled biological (between-plate replicates) with $n=2-3$ mice or rats represented. Statistical significance was assessed by Student's t-test among the biological replicates.

For the single-gene (Reg $3 b$ and Ccl2) qPCR assays, total RNA from newly obtained tissue was reverse transcribed using the TaqMan Reverse Transcription Reagents kit (Applied Biosystems) and transcripts were amplified with TaqMan probe and primers sets specific to Reg3b and Ccl2 on an ABI Prism 7700 Sequence Detection System (Mm00440616_g1 and Mm00441242_m1 for mouse Reg $3 b$ and Ccl2, respectively; Rn00583920_m1 and Rn00580555_m1 for rat Reg3b and Ccl2, respectively). Data were analyzed using the $2^{-\Delta \mathrm{Ct}}$ method as a ratio compared to the housekeeping gene, Gapdh, using the TaqMan Rodent GAPDH Control Reagents kit (Applied Biosystems). In the single-gene study, each reported fold-regulation ratio (CCI vs sham, CFA vs saline) comprises 3 technical (within-plate) replicates and 2-3 (pooled) biological replicates.

We note that these data are characterized by great heterogeneity in the ratios of regulated genes across tissues compared to housekeeping genes. The multi-gene study, like the meta-analysis before it, can be considered primarily hypothesis-generating in nature. For the single-gene qPCR study, by contrast, we were interested in an unbiased, apples-to-apples comparison of fold-regulations by the chronic pain state in each case, using statistically conservative methods. To accomplish this, we employed confidence limits analysis as follows. For each condition and in each biological replicate, the technical error variance was used to generate minimum and maximum point-estimates (95\% confidence intervals $[\mathrm{CI}]$ ) of fold-regulations (pain vs control). Reported are the means of these point estimates along with their 95\% CIs of the biological variance. Statistical significance was defined as the nonoverlap of the $95 \%$ CIs with 1 .

\section{Results}

\subsection{Analysis of significantly regulated genes from 20 independent} microarray experiments

We identified 20 papers from the literature from the years 2002-2008 that describe a microarray analysis of tissue obtained from rodents experiencing a tonic/chronic pain state. The general characteristics of these studies can be found in Table 1. Of these 20 studies, 14 used a neuropathic assay and 6 used an inflammatory assay. Eighteen studies were performed on tissue obtained from rat, 2 studies on tissue obtained from mouse. The tissue from which total RNA was isolated was (or included) spinal cord in 13 studies, DRG in 9 studies, sciatic nerve in 2 studies, and hind paw skin in one study. A compilation of all of the lists of significantly regulated genes from the individual papers revealed a total of 2254 unique genes (not shown; interested parties can obtain the full list from the corresponding author). Of these 2254 genes, 355 genes were observed to be regulated in 2 independent studies, 98 genes were observed to be regulated in 3 studies, 44 genes were observed to be regulated in 4 studies, 16 genes were observed to be regulated in 5 studies, 12 genes were observed to be regulated in 6 studies, 4 genes were observed to be regulated in 7 studies, 2 genes were observed to be regulated in 8 studies, and 1 gene was observed to be regulated in 9 independent studies (Fig. 1a). The binomial probability $(P)$ of observing the same gene in 2,3 , and 4 independent microarray studies was calculated as $P=0.14,0.03$, and 0.006 , respectively. Thus, a unique gene found to be significantly regulated in 3 or more independent microarray studies (out of 20 total) was considered to be statistically significant $(P<0.05)$. The more conservative list of genes that were significantly regulated in 4 or more microarray studies $(P<0.01)$ is reported in Table 2; of the 79 genes on this list, 57 were consistently upregulated by the pain state and 22 were consistently downregulated. The list of genes that were significantly regulated in 3 microarray studies is provided as Supplementary Table 1 online (Appendix).

The average validation score (see Materials and methods) as a function of the number of studies showing regulation of that gene is shown in Fig. 1b. Of interest is the fact that in the intervening period after these validation scores were assigned, new data supporting at least 3 genes' involvement in pain were published: Atp1b3 [26], Reg3b [19], and Vgf [44].

\subsection{Multi-gene qPCR confirmation of genes with 4 or more hits}

In order to validate the ability of this meta-analysis of pain microarray studies to identify true-positive regulated genes with generalizable effects, we performed an independent study using a custom multi-gene qPCR plate. The expression of 79 genes showing 4 or more hits was assessed, de novo, in DRG and spinal cord of rats and mice given a neuropathic (CCI) or inflammatory (CFA) injury, at a single time point associated with maximal levels of mechanical allodynia in each case (14 days postoperative for $\mathrm{CCI}$; 24 hours postinjection for CFA) based on our extensive experience with these algesiometric tests. Note, however, that allodynia was not measured in the subjects providing tissue for the qPCR experiments, and thus it remains possible that the tissue was not obtained at time points corresponding to maximum allodynia. Although qPCR assays were run in biological (between-plate) triplicate; of the 8 conditions ( 2 species $\times 2$ tissues $\times 2$ injuries) examined, one of the replications failed in 2 cases (rat spinal cord CCI and mouse spinal cord CCI) such that statistical significance could not be evaluated. It should be noted, however, that as for the meta-analysis itself, the point of this endeavor was heuristic rather than hypothesis-testing, and thus we considered $>2$-fold 

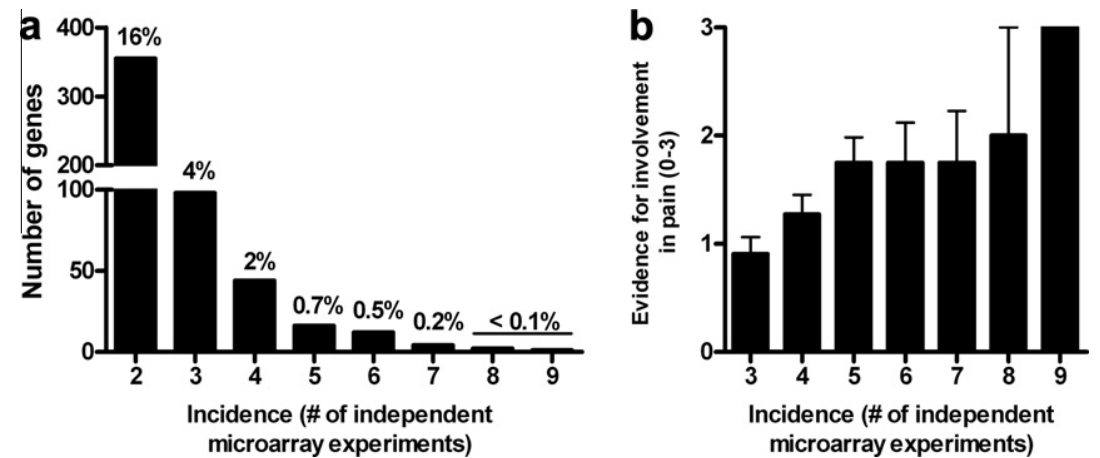

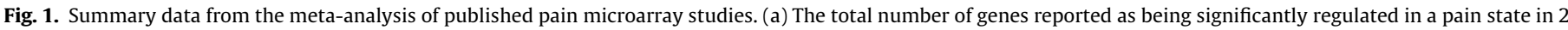

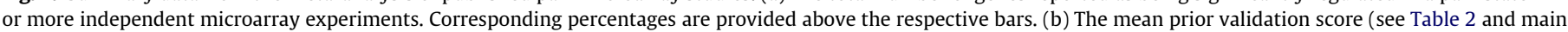
text) for genes reported as being significantly regulated in a pain state in 3 or more independent microarray experiments (mean \pm SD).
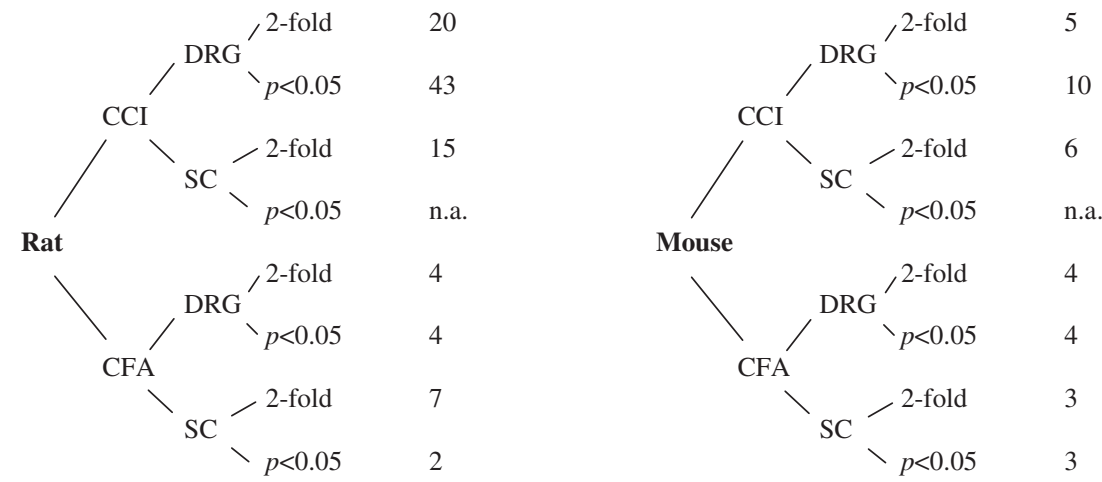

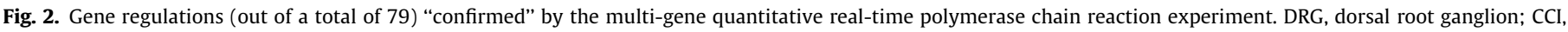
chronic constriction injury; SC, spinal cord; CFA, complete Freund's adjuvant; n.a., not applicable, as statistical analyses could not be performed due to low sample size.
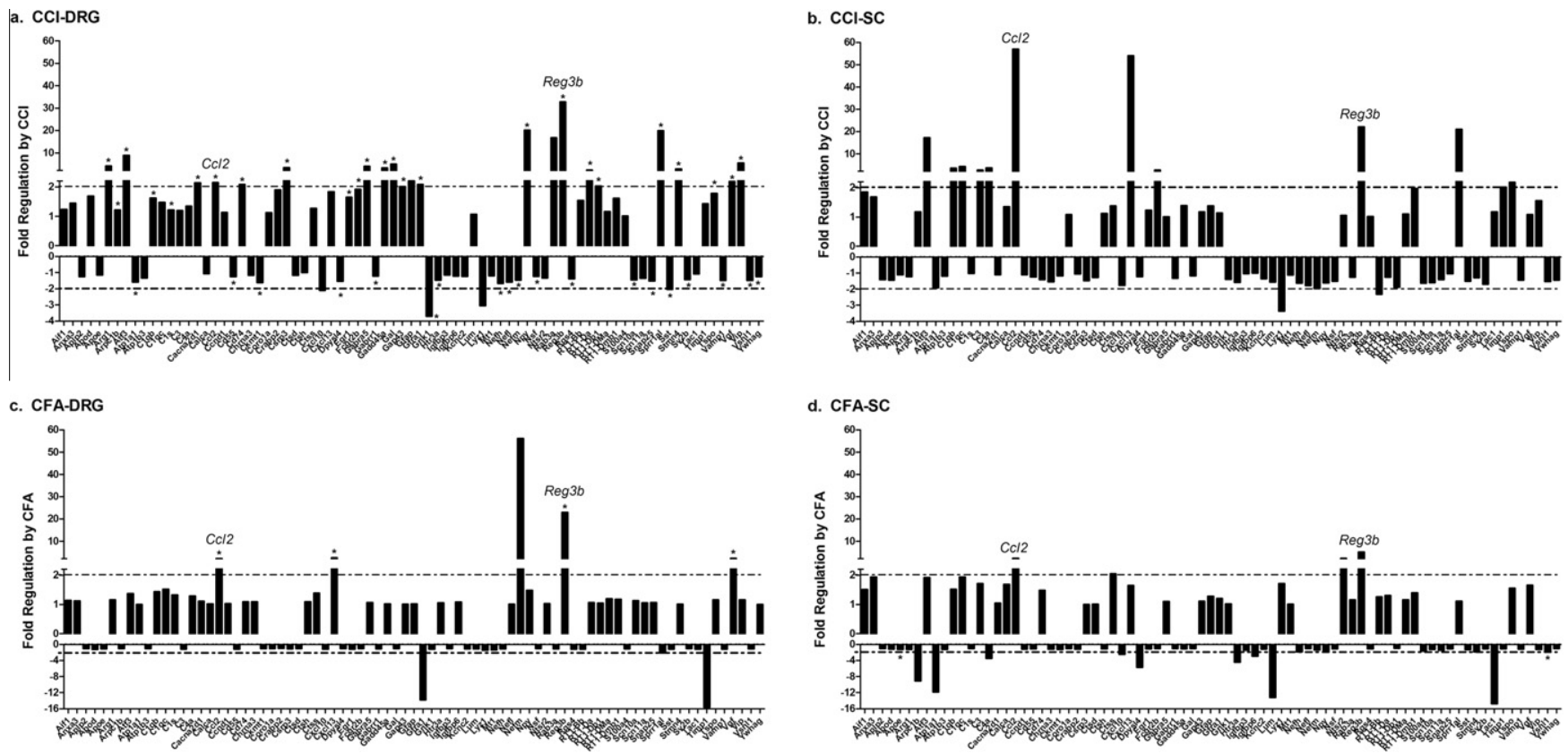

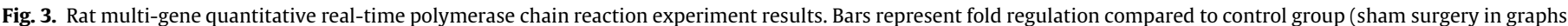

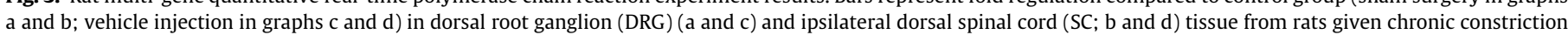

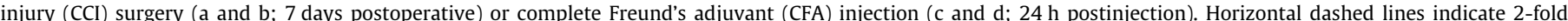

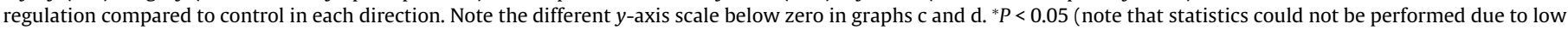
sample size in graph b). 
a. $\mathrm{CCl}$ - DRG vs. SC

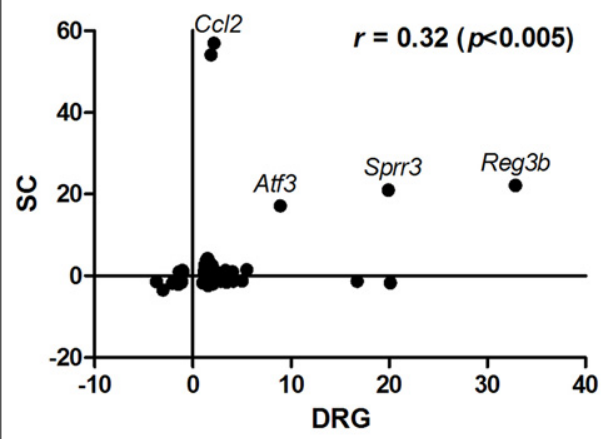

c. DRG - CCI vs. CFA

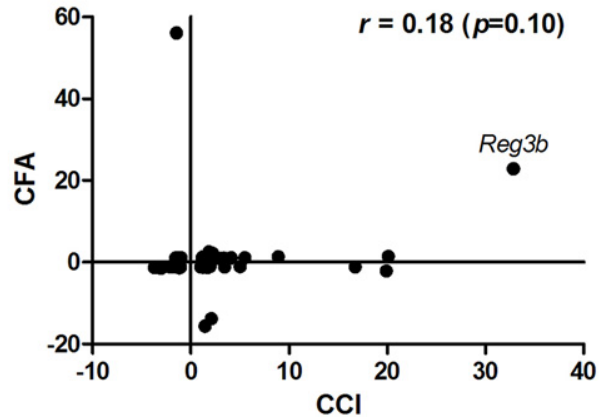

b. CFA - DRG vs. SC

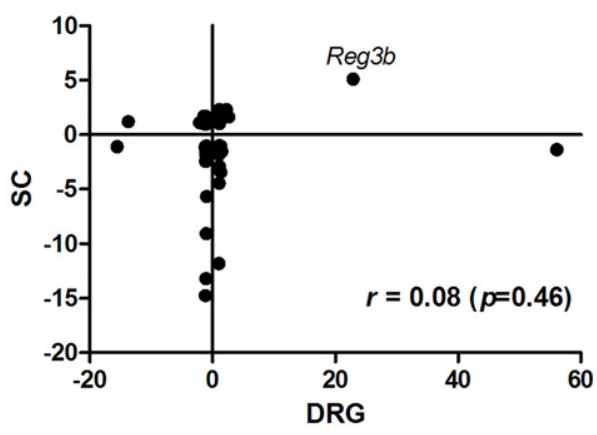

d. SC - CCl vs. CFA

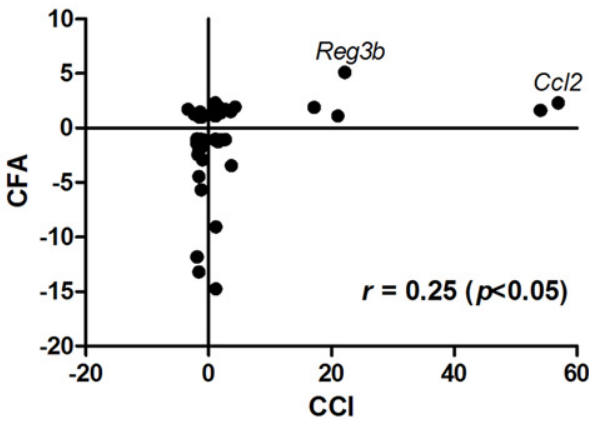

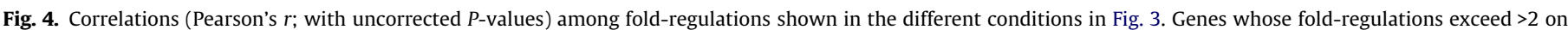
both axes are denoted by name. CCI, chronic constriction injury; DRG, dorsal root ganglion; SC, spinal cord; CFA, complete Freund's adjuvant.

a. CCI-DRG Rat vs. Mouse

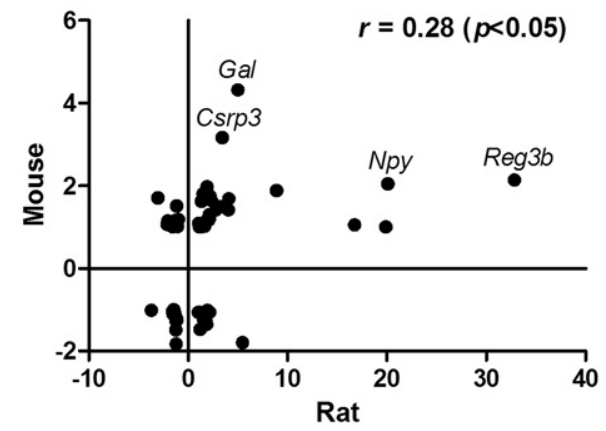

c. CCI-SC Rat vs. Mouse

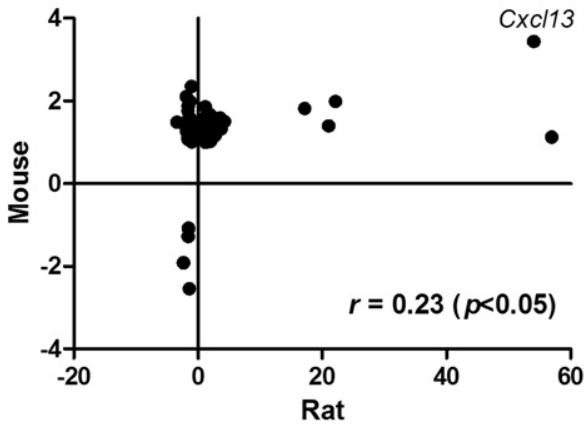

b. CFA-DRG Rat vs. Mouse

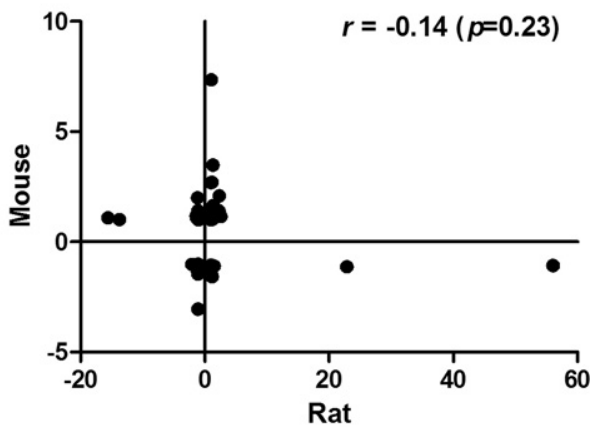

d. CFA-SC Rat vs. Mouse

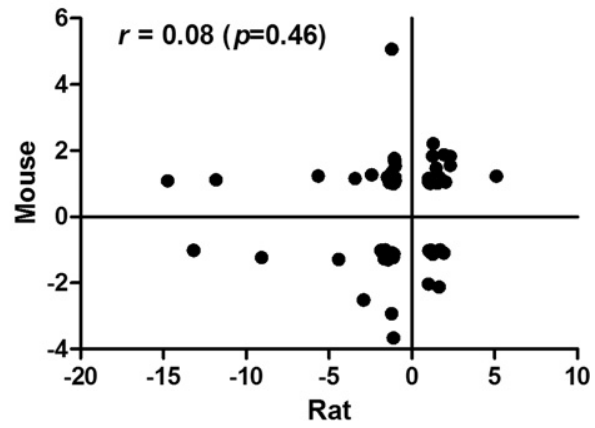

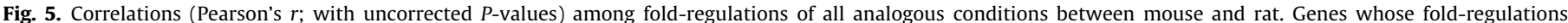

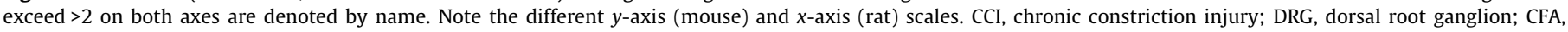
complete Freund's adjuvant; SC, spinal cord. 
a. Regulated in 3+Studies

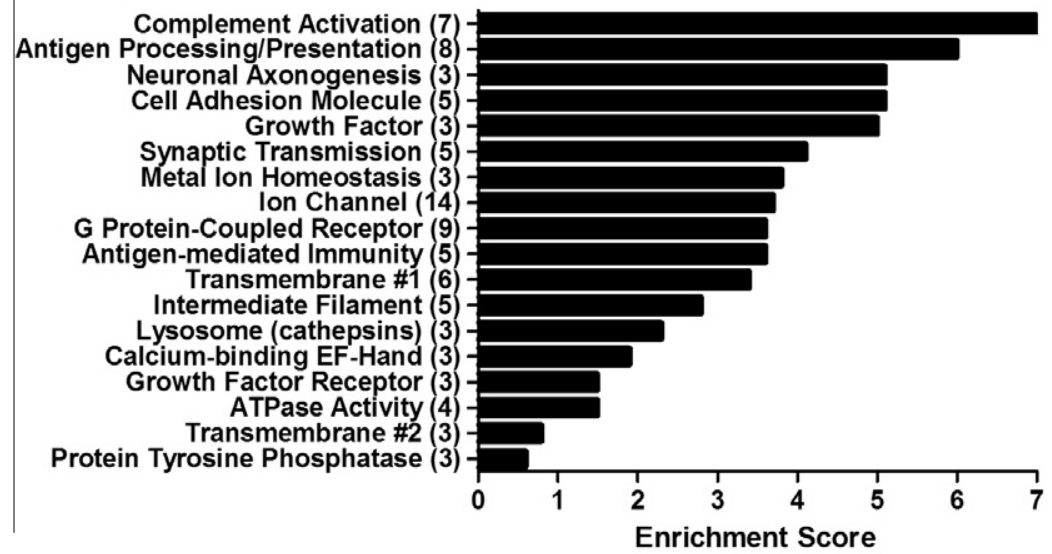

b. Regulated in 4+ Studies

Complement Activation (6) Antigen Processing/Presentation (5) Synaptic Transmission (6) Ion Channel (7) Metal Ion Homeostasis (3) Lysosome (cathepsins) (3) Intermediate Filament (3)

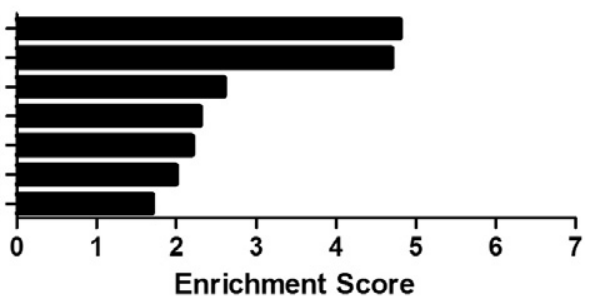

\section{c. Confirmed Regulation in Rat-CCI-DRG}

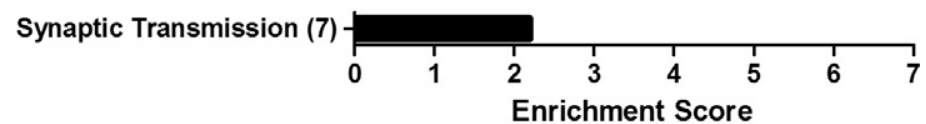

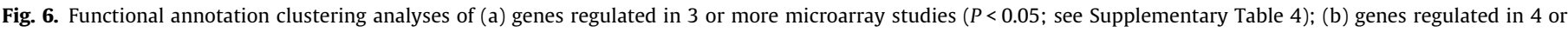

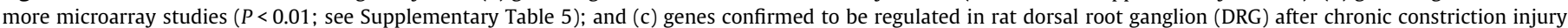

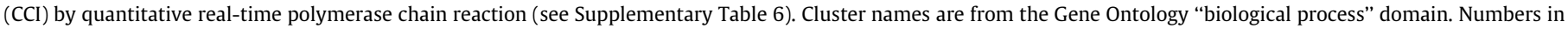
parentheses represent the number of individual genes in the cluster. The enrichment score is a measure of the significance of the gene group to the total gene list.

regulations in the spinal cord-CCI conditions as suggestive of true regulation.

Results of the rat and mouse multi-gene qPCR experiment are shown in Figs. 2 and 3 and Supplementary Tables 2 and 3. As can be seen, a large number of these genes were "confirmed" to be regulated in the direction seen in the original microarray studies in the rat-CCI-DRG condition, with 20 genes displaying $>2$-fold regulation and 43 genes showing statistically significant changes at $P<0.05$ (and 20 genes displaying both $>2$-fold regulation and significance at $P<0.05)$. Although statistical significance could not be evaluated in the rat-CCI-spinal cord condition, a similar number of genes ( 15 vs 20 ) displayed $>2$-fold regulation. In all other conditions, however, far fewer genes were found with either fold-change or statistical evidence of regulation. Pearson correlations of foldregulation levels in the rat are shown in Fig. 4 . The only correlation surviving Bonferroni correction $(P=0.05 / 4=0.0125)$ was between DRG and spinal cord expression levels following CCI.

An unexpected finding was the greatly diminished number of statistically significant or $>2$-fold regulated genes after $\mathrm{CCI}$ in the mouse compared to the rat. Fig. 5 shows Pearson correlations of fold-regulation levels between rat and mouse. In fact, the raw correlations in the $\mathrm{CCI}$ conditions were significant, although not after Bonferroni correction.

\subsection{Functional annotation clustering analyses}

Functional clustering of genes based on Gene Ontology annotation was performed on lists of genes found to be regulated in 3 or more independent microarray experiments (177 genes), 4 or more independent microarray experiments ( 79 genes), and confirmed by subsequent qPCR analysis (rat DRG-CCI; 43 genes) using the Gene Functional Classification tool. The overall pattern of gene clusters by function demonstrated a particular enrichment of genes involved in immune function, cell structure and growth, and cell signaling, among others (Fig. 6). The lists of specific genes identified in these clusters can be found in Supplementary Tables 4-6.

\subsection{Single-gene $q P C R$ of Reg3b and $\mathrm{Ccl} 2$}

The Reg $3 b$ and $C c l 2$ genes were the only genes of the 79 showing reliable regulation across the 4 injury/tissue combinations in the rat (Fig. 3), and Reg3b additionally was upregulated $>2$-fold in both DRG and spinal cord after CCI in the mouse. To confirm these observations with proper hypothesis-testing procedures, we collected tissue in separate cohorts of rats and mice and performed qPCR on these 2 genes individually, using standard qPCR methods. As shown in Fig. 7, we largely confirmed the results of the multigene qPCR study with respect to these 2 genes. Reg $3 b$ was significantly upregulated (ie, fold-regulation significantly $>1$ ) in every condition except mouse-CFA, and $\mathrm{Ccl} 2$ was significantly upregulated in every condition in the rat except CCI-DRG, but none in the mouse. Of interest is the extremely high correlation $(r=0.91$, $P<0.001$ ) between the fold-regulations in this experiment and those obtained in analogous conditions in the multi-gene qPCR study (Fig. 7c), strongly supporting the accuracy of the multi-gene study. 


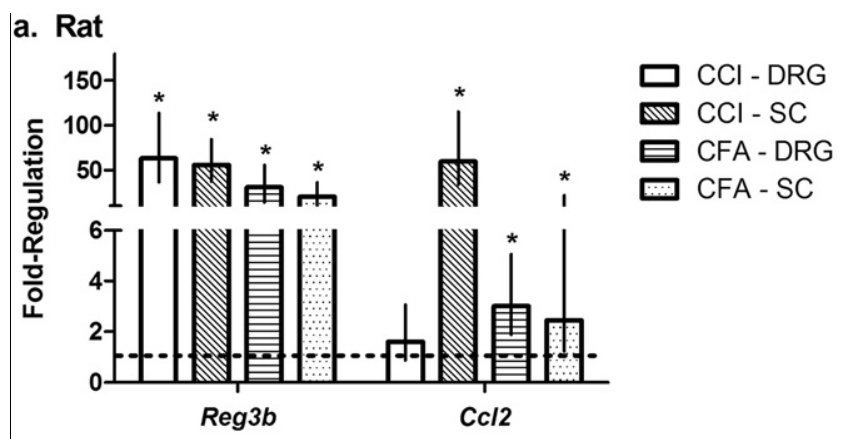

b. Mouse
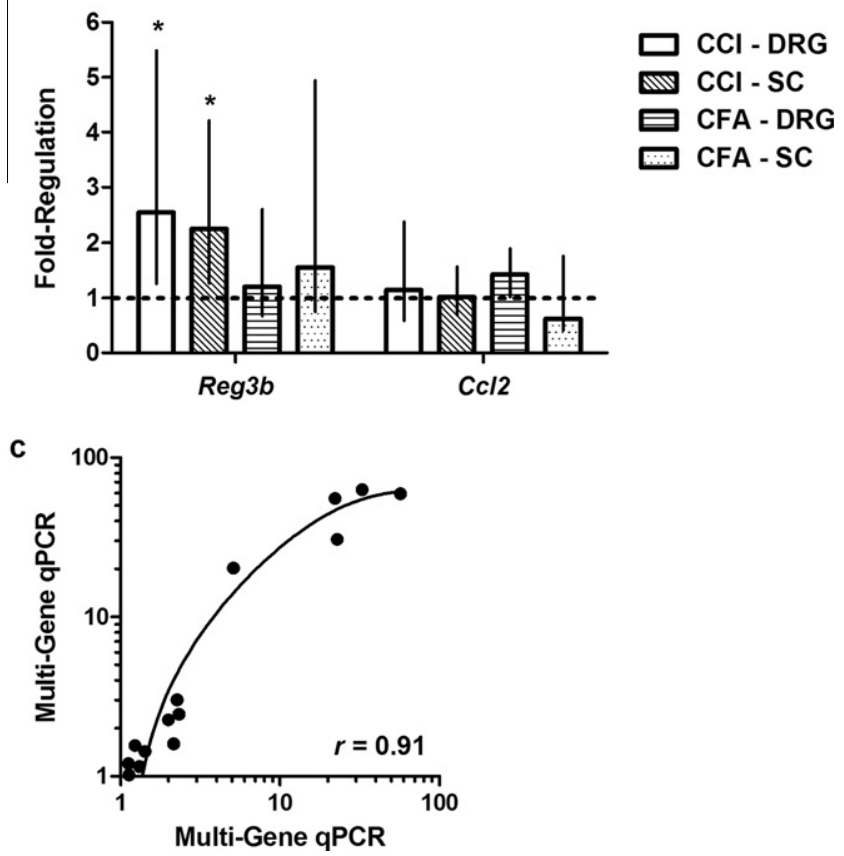

Fig. 7. Single-gene quantitative real-time polymerase chain reaction (qPCR) of Reg $3 b$ and $C c l 2$ in a new cohort of rats (a) and mice (b). Bars represent average foldregulation compared to control (sham surgery for chronic constriction injury [CCI] groups and saline injection for complete Freund's adjuvant [CFA] groups); note the difference in scale in the 2 graphs. Stems represent the $95 \%$ confidence interval over 3 biological replicates. The dashed horizontal line indicates no regulation by pain; statistical significance $\left({ }^{*} P<0.05\right.$; conservatively defined) is achieved for stems not touching this line. Graph c shows the correlation of fold-regulations in the 18 conditions shown in graphs a and b with the analogous conditions in the multi-gene quantitative real-time polymerase chain reaction experiment. SC, spinal cord; DRG, dorsal root ganglion.

\section{Discussion}

Experimental use of high-density oligonucleotide microarrays has provided novel insights into the molecular mechanisms involved in the pathogenesis of chronic pain, in at least 2 cases leading to a successful prediction of genetic association in humans $[11,50]$. However, these insights do not come easily, as highly parallel analyses of gene expression produce large, cumbersome lists of regulated genes, and it remains difficult to tell true positives from false positives and establish both biological significance and generalizability of the implicated proteins.

We performed an analysis of unique microarray experiments from 20 published papers in order find genes that are repeatedly found to be regulated in a persistent pain state. We found a positive relationship between the incidence of significant regulation of a gene in independent microarray experiments and the level of existing "validation" of that gene/protein in the published literature. Of the 79 regulated genes that appeared in 4 or more independent microarray experiments, our meta-analysis found 41 genes with a prior evidence score of 2 or 3, establishing validity of both this analysis and the microarray profiling approach as a whole. Of particular interest to us was the appearance of Atp $1 \mathrm{~b} 3$ $\left(\mathrm{Na}^{+}, \mathrm{K}^{+}\right.$-ATPase, $\beta_{3}$ subunit) on the list, which we recently demonstrated via genetic haplotype mapping to play a role in mediating variability in pain behavior among mouse strains [26], despite the existence of no prior evidence whatsoever linking this protein to pain. With Atp $1 b 3$ as an example, the 38 genes that have little to no prior validation are of potentially considerable import.

\section{1. "Confirmation" of regulated genes via multi-gene qPCR}

We found that when using DRG tissue from nerve-injured rats, over $50 \%$ of the regulations identified by the meta-analysis could be statistically confirmed in a de novo qPCR experiment. Although many of microarray studies used spinal cord tissue, we unfortunately lost one biological replicate due to technical error and could not evaluate our replication "success" in the spinal cord. However, the comparable number of genes displaying $>2$-fold regulation in the spinal cord compared to the DRG and the highly significant correlation between DRG and spinal cord regulations both suggest that many of these genes were likely "confirmed" in this tissue as well.

The inability to confirm gene regulations in all other conditions (rat CFA and all mouse conditions) is likely explained by the paucity of their representation in the original microarray studies. Only 2 of 20 studies (accounting for $<3 \%$ of the unique genes considered) were performed on the mouse, and only 6 of 20 studies (accounting for $<25 \%$ of the unique genes considered) used inflammatory stimuli. It is also likely that nerve damage causes true regulation of a larger number of genes than does inflammation.

It is important to note that our inability to "confirm" many of these gene regulations does not necessarily mean they are false positives. Obviously, none of the study designs from the original papers exactly match each other, nor do they match exactly the design of the multi-gene qPCR experiment. The data of Griffin and colleagues [17] are instructive in this respect: of 612 genes found to be significantly regulated by 3 surgical neuropathic injury models (CCI, spared nerve injury and spinal nerve ligation), only 54 genes $(<9 \%)$ were commonly regulated by all 3 .

Of course, many of the currently identified 79 regulations might indeed be false positives. Much has been said about the reliability and false-positive rates of these techniques from a statistical perspective $[3,18,20]$, but far less is known about the error associated with actual biological differences across multiple experiments over time. Of interest perhaps is the comparison of genes identified by the current meta-analysis with the results of microarray studies published after the current study was conducted. Two studies of DRG expression in rats with surgical nerve injuries revealed a great deal of overlap: 15 genes on the current list were found to be significantly regulated by Vega-Avelaira et al. [54] (including Reg3b and $(\mathrm{cl} 2$ ), and 51 genes by Maratou et al. [32]. A study of trigeminal ganglion mRNA expression after CFA revealed only 5 common genes [39]. Other more recent microarray studies couldn't be analyzed in this way because not all regulated genes were reported $[41,60]$.

\subsection{Specificity of gene regulation}

Although very few individual genes were identified that were commonly regulated across the varying species, injury states, and tissues studied herein, the patterns of regulation observed overall were supportive of certain commonalities. Most notably, the overall correlation between gene regulation in the DRG vs spinal cord 
(comparing all analogous rat and mouse conditions) was $r=0.56$ $(P<0.001)$ (see also [55]). Not surprisingly, much evidence was uncovered for specificity of gene regulation as well. For example, some genes appeared to be neuropathic-specific (at least in the rat), including Atf3, C1qb, Fcgr2b, Nefm, Tspo, and Sprr1al. The clearest example was Sprr1al (small proline-rich protein 1a-like), with 20 -fold upregulation after CCI but no evidence for upregulation after CFA. This gene, like the immediate-early gene, Atf3, is known to be involved in peripheral nerve regeneration [9,47]. Neuropathic-specific upregulation of cytoskeleton-related genes, such as Nefm (neurofilament, medium chain), has also been reported [45].

Perhaps the most striking dissociation is that the range of foldregulations observed in the rat is considerably greater than that observed in the mouse (Fig. 5). Whether this points to species differences in homeostasis or simply to the fact that the list of genes examined was enriched in rat-relevant genes-and that a different list of mouse-relevant genes might be discovered-is not clear. Either possibility would represent a great challenge in comparative pain research.

\subsection{Clusters of pain-regulated genes}

Functional cluster analyses revealed the importance of gene clusters involved in cell signaling (eg, synaptic transmission, ion channels, G protein-coupled receptors), cell structure and growth (eg, intermediate filaments), and especially, immune system activity. Of particular note, a large number of genes involved in the complement cascade were regulated. Their involvement in pain has been previously demonstrated [17,22,52]; our analysis confirms the importance of these findings. Furthermore, the analysis identified a number of additional immune-related gene clusters involved in antigen presentation, cell adhesion, and antigen-mediated immunity. These findings serve to emphasize the importance of the immune system in peripheral neuropathic and inflammatory pain. Finally, a number of relatively novel gene clusters were identified by our functional analyses, including ATPase activity (see [26]], metal ion homeostasis, and protein tyrosine phosphatases.

\subsection{Reg3b and Ccl2 as putative biomarkers of pain}

In light of the profound dissociations by injury and species revealed by the multi-gene qPCR experiment, it is particularly noteworthy that 2 genes-Reg $3 b$ and $C c l 2-$ showed regulation by pain generalizing across injury, tissue, and (for Reg $3 b$ ) species. Genes showing somewhat less robust generalization include Atf3, C1qc, C4a, RT1-Dmb1, and Vgf.

Reg $3 b$, part of a family of "regenerating genes" originally identified in regenerating pancreatic islet cells [51], encodes a secretory protein most commonly called pancreatitis-associated protein (PAP; also known as PAP1, HIP/PAP, Reg-2, peptide 23 and RegIII $\beta$ ), as it is expressed in this inflammatory condition [21]. PAP is massively upregulated in motor neurons and some sensory neurons (including IB4-positive cells in the DRG) after nerve injury $[4,19,30]$. Suggesting a role beyond mitogenesis, and increasing the relevance to pain, are the recent demonstrations that PAP is upregulated in the DRG after CFA $[5,19]$ and cyclophosphamide [49] administration in rats. To date, there is no direct causal evidence linking Reg3b/PAP to pain.

On the other hand, $\mathrm{Ccl}$, encoding the chemokine ( $\mathrm{C}-\mathrm{C}$ motif) ligand 2 (CCL2)-commonly known as monocyte chemoattractant protein-1 (MCP-1)-has with its receptor CCR2 a well-studied role in pain processing, especially in neuropathic pain (see $[1,14]$ ). Upregulation in the DRG by nerve injury and inflammation at the mRNA and protein level, in both neurons and glial cells, has been demonstrated multiple times, but evidence at the spinal cord level is more controversial [14]. Although CCL2 involvement in pain in the mouse has been amply demonstrated via transgenics [33], to our knowledge, only 2 studies have demonstrated upregulation of $\mathrm{Ccl} 2$ after common neuropathic injuries $[13,15]$ in this species, and none after inflammatory injury. The rat vs mouse difference seen here might relate to differences in the timing of $\mathrm{Ccl} 2$ regulation: in a study of DRG expression after $\mathrm{CCI}$ in rats, the peak upregulation was seen at postoperative day 7-14 (the latter being the time point employed here) [61], whereas in a recent study of DRG expression after CCI in mice, the peak upregulation was seen on postoperative day 1 [13].

Intriguingly, for both genes, evidence exists-in humans, no less-that protein levels in accessible tissues and body fluids are increased in inflammatory disorders that often feature pain $[21,31,37,38,40,42]$. In one case, a significant correlation between urinary PAP levels and bladder pain in patients with interstitial cystitis was demonstrated [31], but of course it remains unclear whether this was directly related to pain intensity or disease severity. Overall, in light of the present findings, CCL2 and especially REG3B/PAP ought to be further considered as potential biomarkers of chronic pain.

\section{Conflict of interest statement}

None of the authors have financial or other relationships that might lead to a conflict of interest in the study.

\section{Acknowledgments}

This work was supported by the National Institutes of Health and the Louise and Alan Edwards Foundation (J.S.M.). Thanks to Dr. Gary J. Bennett for useful discussions and generously contributing resources for the rat experiment, and to Guokai Liu for performing the rat CCI surgeries. Thanks also to Connie Matthews from SA Biosciences for her assistance with the multi-gene qPCR study.

\section{Appendix A. Supplementary data}

Supplementary data associated with this article can be found, in the online version, at doi:10.1016/j.pain.2011.04.014.

\section{References}

[1] Abbadie C, Bhangoo S, De Koninck Y, Malcangio M, Melik-Parsadaniantz S, White FA. Chemokines and pain mechanisms. Brain Res Rev 2009;61:125-34.

[2] Alibes A, Yankilevich P, Canada A, Diaz-Uriarte R. IDconverter and IDClight: conversion and annotation of gene and protein IDs. BMC Bioinform 2007;8:9.

[3] Allison DB, Cui X, Page GP, Sabripour M. Microarray data analysis: from disarray to consolidation and consensus. Nature Rev Neurosci 2006;7:55-65.

[4] Averill S, Davis DR, Shortland PJ, Priestley JV, Hunt SP. Dynamic pattern of Reg2 expression in rat sensory neurons after peripheral nerve injury. J Neurosci 2002;22:7493-501.

[5] Averill S, Inglis JJ, King VR, Thompson SWN, Cafferty WBJ, Shortland PJ, Hunt SP, Kidd BL, Priestley JV. Reg-2 expression in dorsal root ganglion neurons after adjuvant-induced monoarthritis. Neuroscience 2008;155:1227-36.

[6] Barr GA, Gao P, Wang S, Cheng J, Qin J, Sibille EL, Pavlidis P. Microarray analysis of gene expression following the formalin test in the infant rat. Pain 2005;117:6-18.

[7] Benjamini Y, Hochberg Y. Controlling the False Discovery Rate: a practical and powerful approach to multiple testing. J Royal Stat Soc Ser B 1995;57:289-300.

[8] Bennett GJ, Xie Y-K. A peripheral mononeuropathy in rat that produces disorders of pain sensation like those seen in man. Pain 1988;33:87-107.

[9] Bonilla IE, Tanabe K, Strittmatter SM. Small proline-rich repeat protein $1 \mathrm{~A}$ is expressed by axotomized neurons and promotes axonal outgrowth. J Neurosci 2002;22:1303-15.

[10] Costigan M, Befort K, Karchewski L, Griffin RS, D'Urso D, Allchorne A, Sitarski J, Mannion JW, Pratt RE, Woolf CJ. Replicate high-density rat genome oligonucleotide microarrays reveal hundreds of regulated genes in the dorsal root ganglion after peripheral nerve injury. BMC Neurosci 2002;3:16. 
[11] Costigan M, Belfer I, Griffin RS, Dai F, Barrett LB, Coppola G, Wu T, Cobos EJ, Zaykin D, Allchorne A, Shen P-H, Nikolajsen L, Karppinen J, Mannikko M, Kelempisioti A, Goldman D, Maixner W, Geschwind DH, Max MB, Seltzer Z, Woolf CJ. Multiple chronic pain states are associated with a common amino acid-changing allele in KCNS1. Brain 2010;133:2519-27.

[12] Dennis Jr G, Sherman BT, Hosack DA, Yang J, Gao W, Lane HC, Lempicki RA. DAVID: database for annotation, visualization, integrated discovery. Genome Biol 2003;4:P3.

[13] Fu ES, Zhang YP, Sagen J, Candiotti KA, Morton PD, Liebl DJ, Bethea JR, Brambilla R. Transgenic inhibition of glial NF-kappa B reduces pain behavior and inflammation after peripheral nerve injury. Pain 2010;148:509-18.

[14] Gao YJ, Ji RR. Chemokines, neuronal-glial interactions, and central processing of neuropathic pain. Pharmacol Ther 2010;126:56-68

[15] Gao YJ, Zhang L, Samad OA, Suter MR, Yasuhiko K, Xu ZZ, Park JY, Lind AL, Ma Q, Ji RR. JNK-induced MCP-1 production in spinal cord astrocytes contributes to central sensitization and neuropathic pain. J Neurosci 2009;29:4096-108.

[16] Geranton SM, Morenilla-Palao C, Hunt SP. A role for transcriptional repressor methyl-CpG-binding protein 2 and plasticity-related gene serum- and glucocorticoid-inducible kinase 1 in the induction of inflammatory pain states. J Neurosci 2007;27:6163-73.

[17] Griffin RS, Costigan M, Brenner GJ, Ma CHE, Scholz J, Moss A, Allchorne A, Stahl GL, Woolf CJ. Complement induction in spinal cord microglia results in anaphylatoxin C5a-mediated pain hypersensitivity. J Neurosci 2007;27:8699-708.

[18] Griffin RS, Mills CD, Costigan M, Woolf CJ. Exploiting microarrays to reveal differential gene expression in the nervous system. Genome Biol 2003:4:105.

[19] He S-Q, Yao J-R, Zhang F-X, Wang Q, Bao L, Zhang X. Inflammation and nerve injury induce expression of pancreatitis-associated protein-II in primary sensory neurons. Mol Pain 2010;6:23.

[20] Ioannidis JPA, Allison DB, Ball CA, Coulibaly I, Cui X, Culhane AC, Falchi M, Furlanello C, Game L, Jurman G, Mangion J, Mehta T, Nitzberg M, Page GP, Petretto E, van Noort V. Repeatability of published microarray gene expression analyses. Nat Genet 2009;41:149-55.

[21] Iovanna JL, Keim V, Nordback I, Montalto G, Camarena J, Letoublon C, Levy P, Berthezene P, Dagorn JC. Serum levels of pancreatitis-associated protein as indicators of the course of acute pancreatitis. Multicentric study group on acute pancreatitis. Gastroenterology 1994;106:728-34.

[22] Jang JH, Clark JD, Li X, Yorek MS, Usachev YM, Brennan TJ. Nociceptive sensitization by complement C5a and C3a in mouse. Pain 2010;148:343-52.

[23] Ko J, Na DS, Lee YH, Shin SY, Kim JH, Hwang BG, Min BI, Park DS, cDNA microarray analysis of the differential gene expression in the neuropathic pain and electroacupuncture treatment models. J Biochem Mol Biol 2002;35:420-7.

[24] Kubo T, Yamashita T, Yamaguchi A, Hosokawa K, Tohyama M. Analysis of genes induced in peripheral nerve after axotomy using cDNA microarrays. J Neurochem 2002;82:1129-36.

[25] LaCroix-Fralish ML, Ledoux JB, Mogil JS. The Pain Genes Database: an interactive web browser of pain-related transgenic knockout studies. Pain 2007;131. 3.e1-e4.

[26] LaCroix-Fralish ML, Mo G, Smith SB, Sotocinal SB, Ritchie J, Austin J-S, Melmed K, Schorscher-Petcu A, Laferriere AC, Lee TH, Romanovsky D, Liao G, Behlke MA, Clark DJ, Peltz G, Seguela P, Dobretsov M, Mogil JS. The $\beta 3$ subunit of the $\mathrm{Na}^{+}, \mathrm{K}^{+}$-ATPase affects pain sensitivity. Pain 2009;144:294-302.

[27] LaCroix-Fralish ML, Tawfik VL, Tanga FY, Spratt KF, DeLeo JA. Differential spinal cord gene expression in rodent models of radicular and neuropathic pain. Anesthesiology 2006;104:1283-92.

[28] Levin ME, Jin JG, Ji RR, Tong J, Pomonis JD, Lavery DJ, Miller SW, Chiang LW. Complement activation in the peripheral nervous system following the spinal nerve ligation model of neuropathic pain. Pain 2008;137:182-201.

[29] Lipshutz RJ, Fodor SP, Gingeras TR, Lockhart DJ. High density synthetic oligonucleotide arrays. Nat Genet 1999;21:20-4.

[30] Livesey FJ, O'Brien JA, Li M, Smith AG, Murphy LJ, Hunt SP. A Schwann cell mitogen accompanying regeneration of motor neurons. Nature 1997;390:614-8.

[31] Makino T, Kawashima H, Konishi H, Nakatani T, Kiyama H. Elevated urinary levels and urothelial expression of hepatocarcinoma-intestine-pancreas/ pancreatitis-associated protein in patients with interstitial cystitis. Urology 2010;75:933-7.

[32] Maratou K, Wallace VCJ, Hasnie FS, Okuse K, Hosseini R, Jina N, Blackbeard J, Pheby T, Orengo C, Dickenson AH, McMahon SB, Rice ASC. Comparison of dorsal root ganglion gene expression in rat models of traumatic and HIVassociated neuropathic pain. Eur J Pain 2009;13:387-98.

[33] Menetski J, Mistry S, Lu M, Mudgett JS, Ransohoff RM, Demartino JA, MacIntyre DE, Abbadie C. Mice overexpressing chemokine ligand 2 (CCL2) in astrocytes display enhanced nociceptive responses. Neuroscience 2007;149:706-44.

[34] Mogil JS. Animal models of pain: progress and challenges. Nat Rev Neurosci 2009;10:283-94

[35] Nesic O, Lee J, Johnson KM, Ye Z, Xu G-Y, Unabia GC, Wood TG, McAdoo DJ, Westlund KN, Hulsebosch CE, Perez-Polo JR. Transcriptional profiling of spinal cord injury-induced central neuropathic pain. J Neurochem 2005:95:998-1014

[36] Nishida K, Kuchiiwa S, Oiso S, Futagawa T, Masuda S, Takeda Y, Yamada K. Upregulation of matrix metalloproteinase-3 in the dorsal root ganglion of rats with paclitaxel-induced neuropathy. Cancer Sci 2008;99:1618-25.

[37] Ochi K, Kohriyama T, Higaki M, Ikeda J, Harada A, Nakamura S. Changes in serum macrophage-related factors in patients with chronic inflammatory demyelinating polyneuropathy caused by intravenous immunoglobulin therapy. J Neurol Sci 2003;208:43-50.
[38] Ogawa H, Fukushima K, Naito H, Funayama Y, Unno M, Takahashi K, Kitayama $\mathrm{T}$, Matsuno $\mathrm{S}$, Ohtani $\mathrm{H}$, Takasawa S, Okamoto $\mathrm{H}$, Sasaki I. Increased expression of HIP/PAP and regenerating gene III in human inflammatory bowel disease and a murine bacterial reconstitution model. Inflamm Bowel Dis 2003;9:162-70.

[39] Okumura M, Iwata K, Yasuda K, Inoue K, Shinoda M, Honda K, Shibuta K, Yasuda $\mathrm{M}$, Kondo $\mathrm{E}$. Alternation of gene expression in trigeminal ganglion neurons following complete Freund's adjuvant or capsaicin injection into the rat face. J Mol Neurosci 2010;42:200-9.

[40] Orlikowski D, Chazaud B, Plonquet A, Poron F, Sharshar T, Maison P, Raphael JC, Gherardi RK, Creange A. Monocyte chemoattractant protein 1 and chemokine receptor CCR2 productions in Guillain-Barre syndrome and experimental autoimmune neuritis. J Neuroimmunol 2003;134:118-27.

[41] Persson A-K, Gebauer M, Jordan S, Metz-Weidmann C, Schulte AM, Schneider H-C, Ding-Pfennigdorff D, Thun J, Xu X-J, Wiesenfeld-Hallin Z, Darvasi A, Fried $\mathrm{K}$, Devor $\mathrm{M}$. Correlational analysis for identifying genes whose regulation contributes to chronic neuropathic pain. Mol Pain 2009;5:7.

[42] Press R, Pashenkov M, Jin JP, Link H. Aberrated levels of cerebrospinal fluid chemokines in Guillain-Barre syndrome and chronic inflammatory demyelinating polyradiculoneuropathy. J Clin Immunol 2003;23:259-67.

[43] Ren K, Novikova SI, He F, Dubner R, Lidow MS. Neonatal local noxious insult affects gene expression in the spinal dorsal horn of adult rats. Mol Pain 2005; $1: 27$

[44] Riedl MS, Braun PD, Kitto KF, Roiko SA, Anderson LB, Honda CN, Fairbanks CA Vulchanova L. Proteomic analysis uncovers novel actions of the neurosecretory protein VGF in nociceptive processing. J Neurosci 2009;29:13377-88.

[45] Rodriguez Parkitna J, Korostynski M, Kaminska-Chowaniec D, Obara I, Mika J Przewlocka B, Przewlocki R. Comparison of gene expression profiles in neuropathic and inflammatory pain. J Physiol Pharmacol 2006;57:401-14.

[46] Schena M, Shalon D, Davis RW, Brown PO. Quantitative monitoring of gene expression patterns with a complimentary DNA microarray. Science 1995;270:467-70.

[47] Seijffers R, Mills CD, Woolf CJ. ATF3 increases the intrinsic growth state of DRG neurons to enhance peripheral nerve regeneration. J Neurosci 2007;27:7911-20.

[48] Sun H, Xu J, Della Penna KB, Benz RJ, Kinose F, Holder DJ, Koblan KS, Gerhold DL, Wang H. Dorsal horn-enriched genes identified by DNA microarray, in situ hybridization and immunohistochemistry. BMC Neurosci 2002;3:11.

[49] Takahara Y, Suzuki A, Maeda M, Kawashima H, Nakatani T, Kiyama H Expression of pancreatitis associated proteins in urothelium and urinary afferent neurons following cyclophosphamide induced cystitis. J Urol 2008;179:1603-9.

[50] Tegeder I, Costigan M, Griffin RS, Abele A, Belfer I, Schmidt H, Ehnert C, Nejim J Marian C, Scholz J, Wu T, Allchorne A, Diatchenko L, Binshtok AM, Goldman D, Adolph J, Sama S, Atlas SJ, Carlezon WA, Parsegian A, Lotsch J, Fillingim RB, Maixner W, Geisslinger G, Max MB, Woolf CJ. GTP cyclohydrolase and tetrahydrobiopterin regulate pain sensitivity and persistence. Nat Med 2006;12:1269-77.

[51] Terazono K, Yamamoto H, Takasawa S, Shiga K, Yonemura Y, Tochino Y, Okamoto $\mathrm{H}$. A novel gene activated in regenerating islets. J Biol Chem 1988;263:2111-4.

[52] Twining CM, Sloane EM, Schoeniger DK, Milligan ED, Martin D, Marsh H, Maie SF, Watkins LR Activation of the spinal cord complement cascade might contribute to mechanical allodynia induced by three animal models of spinal sensitization. J Pain 2005;6:174-83.

[53] Valder CR, Liu J-J, Song Y-H, Luo ZD. Coupling gene chip analyses and rat genetic variances in identifying potential target genes that may contribute to neuropathic allodynia development. J Neurochem 2003;87:560-73.

[54] Vega-Avelaira D, Geranton SM, Fitzgerald M. Differential regulation of immune responses and macrophage/neuron interactions in the dorsal root ganglion in young and adult rats following nerve injury. Mol Pain 2009;5:70.

[55] Wang H, Sun H, Della Penna KB, Benz RJ, Xu J, Gerhold DL, Holder DJ, Koblan KS. Chronic neuropathic pain is accompanied by global changes in gene expression and shares pathobiology with neurodegenerative diseases. Neuroscience 2002;114:529-46.

56] Xiao H-S, Huang Q-H, Zhang F-X, Bao L, Lu Y-J, Guo C, Yang L, Huang W-J, Fu G Xu S-H, Cheng X-P, Yan Q Zhu Z-D, Zhang X, Chen Z, Han Z-G, Zhang X. Identification of gene expression profile of dorsal root ganglion in the rat peripheral axotomy model of neuropathic pain. Proc Natl Acad Sci USA 2002;99:8360-65.

[57] Yang H-YT, Mitchell K, Keller JM, Iadarola MJ. Peripheral inflammation increases Scya2 expression in sensory ganglia and cytokine and endothelia related gene expression in inflamed tissue. J Neurochem 2007;103:1628-43.

[58] Yang L, Zhang F-X, Huang F, Lu Y-J, Li G-D, Bao L, Xiao H-S, Zhang X. Periphera nerve injury induces trans-synaptic modification of channels, receptors and signal pathways in rat dorsal spinal cord. Eur J Neurosci 2004;19:871-83.

[59] Yukhananov R, Kissin I. Persistent changes in spinal cord gene expression afte recovery from inflammatory hyperalgesia: a preliminary study on pain memory. BMC Neurosci 2008;9:32.

60] Zhang FX, Liu XJ, Gong LQ, Yao JR, Li KC, Li ZY, Lin LB, Lu YJ, Xiao HS, Bao L, Zhang $\mathrm{XH}$, Zhang $\mathrm{X}$. Inhibition of inflammatory pain by activating B-type natriuretic peptide signal pathway in nociceptive sensory neurons. J Neurosci 2010;30:10927-38.

61] Zhang J, De Koninck Y. Spatial and temporal relationship between monocyte chemoattractant protein-1 expression and spinal glial activation following peripheral nerve injury. J Neurochem 2006;97:772-83.

[62] Zimmermann M. Ethical guidelines for investigations of experimental pain in conscious animals. Pain 1983;16:109-10. 